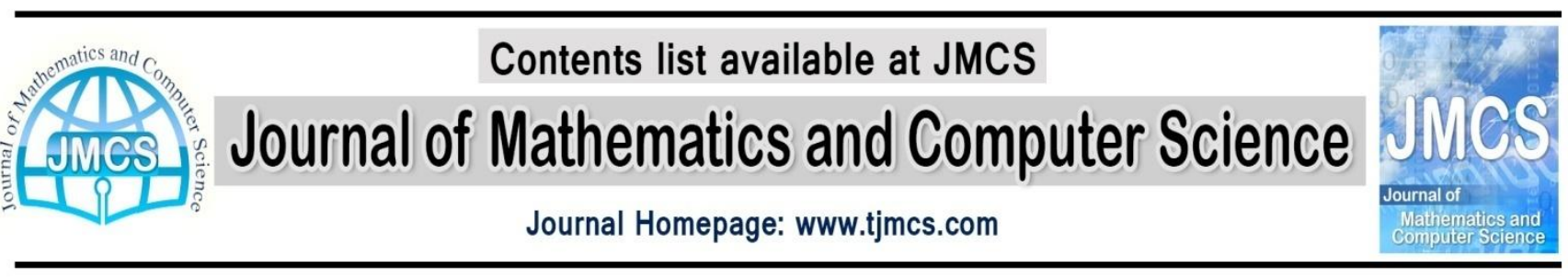

\title{
The Impact of Service Quality on Customer Satisfaction in Internet Banking
}

\author{
S. Fatemeh Sakhaei \\ Faculty of Engineering, Shomal University, Amol, Iran \\ ssfsakhaeiie88@gmail.com \\ Ahmad J. Afshari \\ Faculty of Engineering, Shomal University, Amol, Iran \\ afshari@shomal.ac.ir \\ Ezzatollah Esmaili \\ Faculty of Management, Azad University, Tehran, Iran \\ e.esmaeili@nioc.ir
}

Article history:

Received September 2013

Accepted October 2013

Available online October 2013

\section{Abstract}

This paper presents a study to investigate service quality indexes in Internet Banking. This is an applied research study of descriptive-surveying kind .The purpose of this research is to understand the impact of service quality factors of Internet Banking on customer satisfaction in Iran .To study the relation between service quality and customer satisfaction, first a hybrid model based on the previous works has been proposed. Six service quality dimensions namely reliability, efficiency, responsiveness, fulfillment, security / privacy and website design have been established based on the literature review. The data were gathered through survey interview by a questionnaire that was designed on a 5-Point Likert scale .This study evaluated influence of service quality on customer satisfaction in Internet Banking .The study shows that the Six service quality dimensions has meaningful relationship with customer satisfaction in Internet Banking and reliability has most relation and website design has least relation to customer satisfaction.

Keywords: Internet Banking, Electronic Service Quality, Customer Satisfaction. 


\section{Introduction}

The emergence of Internet has changed the business landscape. The Internet is an extremely important new technology in this era. One particularly important application of the internet is the area of banks and financial institutions [2]. Today, with development of information technology and offering Internet services, network management issues and providing optimal service quality are considered as important issues [12]. Growth of Electronic banking in a country depends on many factors, such as success of internet access ,new online banking features, household growth of internet usage ,dependable services to the customers for which they may be relatively satisfied than of manual system of banking [13].EService quality evaluation results can be used as a basis for e-service quality improvement as well as the improvement of enterprise efficiency, competitiveness and attractiveness in the virtual market [10].The traditional service quality dimensions cannot directly apply to internet banking, because it represents a different and unique service delivery process[15]. E-banking has become important phenomenon in the banking industry and it will continue as more progress and innovations are made in information technology [4].

To understand satisfaction in the e-commerce context, we need to have a clear understanding of what it meant by customer satisfaction. Customer satisfaction is defined as a result of a cognitive and affective evaluation, where some comparison standard is compared to the actually perceived performance. If the perceived is less than expected, customers will be dissatisfied. On the other hand, if the perceived performance exceeds expectations, customers will be satisfied [7]. Effective customer satisfaction investigation is a very important precondition for e-commerce area to win in market competition [3].

The rationale of this research is to recognize the impact of service quality factors on customer satisfaction in internet banking. Research questions which the study will try to get answer are given below:

i) What are the service quality dimensions to satisfy the customers in e-banking?

ii) Which System is appropriate for measuring the factors affecting customer satisfaction in internet banking?

iii) How much is the impact of each of the criteria of e-banking services, on customer satisfaction?

Therefore, this study sought to identify service quality factors in internet banking and present a model to measure customer satisfaction that would be appropriate in the Internet environment, because Due to the vast capabilities of the Internet environment, a dis satisfied customer, with one click, can change the service provider.So, the online monitoring of customer satisfaction is extremely important.

\section{Literature Review}

E-Service is a service delivered to a customer or a potential buyer through a web site .E-Service quality is defined as difference between the service that a customer or a user of particular web site expects and the one actually provided by the web site [11]. Awad found that four e-commerce activities are available 
to Internet users [1]: (1) shopping, (2) banking, (3) investing, and (4) online electronic payment for Internet services. The first formal definition of website quality was provided by Zeithaml, Parasuraman and Malhotra [21]:"the extent to which a web site facilitates efficient and effective shopping, purchasing, and delivery of product and services."

Although the discussion about the e-service and its quality began only with the onest of the information society in Europe, there are numerous systems dealing with the evaluation of the e-service quality [10]. Zeithaml, Parasuraman and Malhotra developed the e-servqual measure for electronic service quality to study customer's judge about service quality. They identified seven dimensions-efficiency, reliability, fulfillment, privacy, responsiveness, recovery and contact to measure customer perception of service quality in online field [21], [22]. Lociacono, Watson and Goodhue planed a system which called Web Qual, and is used for measurement of website quality [9]. Wolfinberger and Gilly presented a scale named .comQ with four factors website design, reliability, security/privacy and customer service [19]. Wolfinberger and Gilly developed the eTailQ system to measuring the quality of online retail shopping [20]. In 2004 Web and Web suggested Site Qual system that can be used in creation and upgrading of the B2C websites. WebQual system in 2005 is renamed e.Qual. This model is based on user perceptions and its importance. The difference between the factors appears if they measure different types of service, so one type of factors are used in evaluation of the online shopping, and the other type of factors are used service buying [10].

Saha and Zhao identified nine service quality dimensions in internet banking they are efficiency, reliability, responsiveness, fulfillment, privacy, communications, personalization, technology update and logistic/technical equipment [15]. First five dimensions were tested as a core dimensions in internet banking. Communication and personalization were identified as another two important service quality dimensions in internet banking. Fasanghari and Roudsari established a customer satisfaction evaluation method based on combination of linguistic variables, fuzzy triangular numbers, and fuzzy entropy. They found that the designed evaluation method creates suitable results and the evaluation could be done as well as possible [3]. Nupur investigated the impact of variables of e-banking on customer satisfaction in Bangladesh and argued that reliability, responsiveness, assurance, empathy and tangibles are the core service quality dimensions for customer satisfaction in e-banking [13]. Musiime and Ramadhan argued that the factors that influence consumer adoption of Internet banking services and found positive relationship between internet banking service, customer adoption and customer satisfaction in Uganda, Africa [11]. They also found that the bank should not be complacent; instead it should be creative and innovative creating new products or services that can stimulate the demand to use inter net banking services. Kumbhar argued that perceived value, brand perception, cost effectiveness, easy to use, convenience, problem handling, security/assurance and responsiveness are important factors in customer satisfaction in e-banking [6]. Gradeyan and Akinyosoye argued that there is positive relation between customer satisfaction and service quality in e-banking in Sierra Leone, their study has shown the various benefits accruing to internet banking, and that many people are increasingly using this service [4]. Also Timothy studied this relation in Nigerian Bank Industry [16]. Saeidipour, Vatandost and Akbari Studied the effect of development of electronic banking on customer satisfaction levels by using Kano model in Refah Bank of Kermanshah, Iran [14]. Jayanthi and Umarani found that nearly 90 percent of the customers, who use internet for their banking operations, prefer internet banking to manual banking [5]. The main reasons are convenience (24 hours services, anywhere connectivity) and time saving (no queues and waiting time) [5]. The concept of quality service goes beyond the technical aspects of providing the service - it includes customers' perception of what the services are to be conveyed [17]. 
In this research has tried to provide a model to study the dimensions of service quality in internet banking and examined the influence of service quality and customer satisfaction in internet banking. The main purpose of this study is to analyze the customer satisfaction level in internet banking in Iran.

\section{Methodology of the study}

Based on the previous works, Saha and Zhao's model and Zeithaml, Parasuraman and Malhotra (2002), provided a model [15], [22]. In this model identified six service quality dimensions -Reliability, Efficiency, Responsiveness, Fulfillment, Privacy/Security and Website Design. The Website Design factor added and examined influence of this factor to customer satisfaction in internet banking. In Figure 1 the theoretical framework of the study is shown.

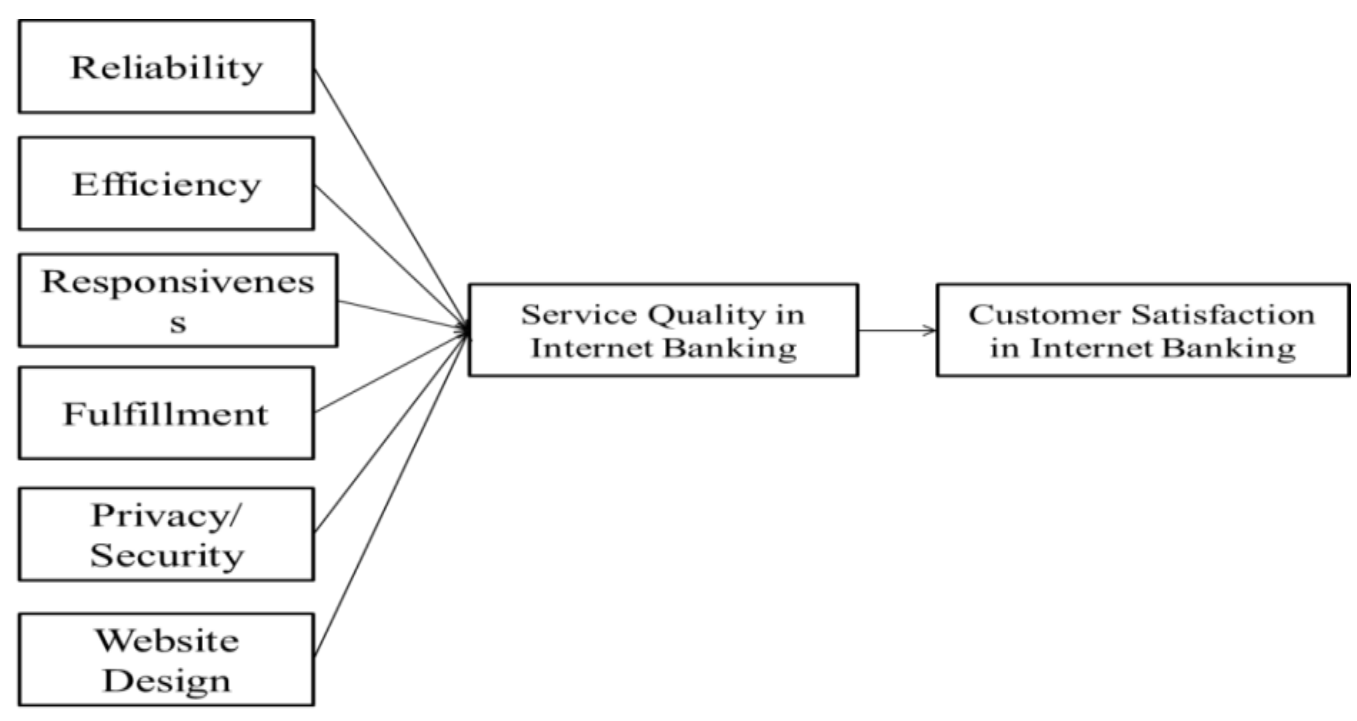

Figure1.The conceptual frame work of this study

\section{Hypothesis:}

The proposed study considers the following hypotheses,

1. Reliability has relationship with service quality in Internet Banking.

2. Efficiency has relationship with service quality in Internet Banking.

3. Responsiveness has relationship with service quality in Internet Banking.

4. Fulfillment has relationship with service quality in Internet Banking.

5. Privacy/Security has relationship with service quality in Internet Banking.

6. Website Design has relationship with service quality in Internet Banking.

7. Service quality has relationship with customer satisfaction in Internet Banking. 
8. There is a significant difference between customer satisfaction in Internet Banking and use of different banks website.

In this section, variables of research were defined.

Reliability: The technical functioning of the site, Information that is provided is accurate [22], [15].

Efficiency: The ability of the customer to get a web site, find their desired product and information associated with it [15], [22].

Responsiveness: The ability of e-retailers to provide appropriate information to customer, when a problem occurs, Willingness to help customers and provide prompt service [15], [22].

Fulfillment: Accuracy of service promises, delivery the product in the promised time [15], [22].

Security/privacy: Personal information are not Shared, credit card information is secured [15], [22].

Website design: The visual appeal of web links organized customized search functions, fast access, and ease of error correction [8].

This is an applied research study of descriptive-surveying kind. The data were collected by using questionnaire. It should be noted that, in the design of the questionnaire, the questionnaire of the master thesis of Saha and Zhao also are used [15]. Questionnaire consisted of two parts. Part-one is demographic characteristic of the sample. Part-two consisted of 41 positive worded statements pertaining to measure satisfaction of internet banking. Statements 1 to 7 for satisfaction of reliability, statements 8 to 14 for satisfaction of efficiency, statements 15 to 21 for satisfaction of responsiveness, statements 22 to 25 for satisfaction of fulfillment, statements 26 to 30 for security/privacy of satisfaction, statements 30 to 35 for website design, and questions 36 to 41 designed to measure the total satisfaction.

The data were collected from costumers that use internet bank services in Tehran, Iran, during the month of April to July 2013. Survey was conducted using Likert Based questionnaire ranging from $1=$ strongly disagree to $5=$ strongly agree. In this study, the population has a large size and geographical area. Then, the researcher selects sampling method Our total study population was infinite, statistically and so According to the Morgan Table 384 sample size was taken. The customers were selected by random sampling method .In this Study an infinite population size is assumed, by to go with Morgan's table, a sample size of 384, has been taken. The reliability of constructs was tested by using Cronbach's alpha test, using SPSS18. Cronbach's alpha coefficients were calculated 0.8 for the questionnaire survey, Because Alpha $\geq 0.7$, the reliability of the questionnaire is acceptable.

\section{Analysis and Findings}

Table 1 shows the demographic profiles of respondents .The respondents consist of female (54.2\%) and male (45.8\%). Most of the respondents is between the ages 25-39(52.6\%). Most of the respondents earned income less than 3,000,000 Rials (33.1\%), (9.9\%) have income between 3,000,000-4,999,000 Rials, (12.8\%) have income between 5,000,000-6,999,000 Rials, (15.6\%) have income between 7,000,000-8,999,000 Rials,(28.6\%) have income over 9000,000 Rials. $18.2 \%$ of respondents use Mellat 's website, $25.8 \%$ of respondents use Tejarat 's website, $18.2 \%$ of respondents use Parsian 's website, $16.4 \%$ of respondents use Pasargads 's website, $18.2 \%$ of respondents use Melli 's website, and $5.5 \%$ of respondents use other banks.

Table1. Profile of respondents 


\begin{tabular}{|c|c|}
\hline percentage & \\
\hline 45.8 & Gender Male \\
\hline 54.2 & Female \\
\hline 6.5 & Age \\
\hline 29.4 & $18-25$ \\
\hline 52.6 & $26-39$ \\
\hline 11.5 & $>40$ \\
\hline 33.1 & Income $<3000$ \\
\hline 9.9 & $3000-4995$ \\
\hline 12.8 & $5000-6999$ \\
\hline 15.6 & $7000-8999$ \\
\hline 28.6 & $>9000$ \\
\hline 18.2 & Bank Mellat \\
\hline 25.8 & Tejarat \\
\hline 18.2 & Pasian \\
\hline 16.4 & Pasargad \\
\hline 15.9 & Melli \\
\hline 5.5 & Other \\
\hline
\end{tabular}

Table 2 is shown descriptive statistics of the variables.

Table2. Descriptive statistics of main variables

\begin{tabular}{|l|c|c|c|c|c|c|c|}
\hline Variable & Number & Rank & $\begin{array}{r}\text { Minimu } \\
\mathrm{m}\end{array}$ & Maximum & Average & Standard deviation & Variance \\
\hline Reliability(R) & 384 & 15 & 13 & 28 & 21.2734 & 2.5139 & 6.319 \\
Efficiency (E) & 384 & 19 & 11 & 30 & 20.7214 & 2.6889 & 7.230 \\
Responsiveness(RE) & 384 & 24 & 6 & 30 & 19.6120 & 3.594 & 12.917 \\
Fulfillment (F) & 384 & 9 & 6 & 15 & 10.4219 & 1.6867 & 2.845 \\
Privacy /security(P) & 384 & 16 & 4 & 20 & 13.7526 & 2.4364 & 5.936 \\
Website Design(WD) & 384 & 12 & 8 & 20 & 13.2214 & 2.2157 & 4.909 \\
Quality of Service(SQ) & 384 & 77 & 66 & 143 & 99.0026 & 9.5994 & 92.149 \\
Customer satisfaction(SAT) & 384 & 36 & 24 & 60, & 41.7 & 5.2177 & 27.225 \\
& & & & & & & \\
& & & & & & & \\
\hline
\end{tabular}

Based on the data from Table 2 can be seen that the average of variables reliability, efficiency, responsiveness, fulfillment, privacy and website design, are equivalent to $21.2734,20.4214,19.6120$, $10.4219,13.7526$ and 13.2214. Dependent variable customer satisfaction in internet banking is 41.7.

First, we need to analyze the data to understand that the data is normal or not, For the purpose of this object Kolmogorov - Smirnov (K-S) is used to check the normality of the variables. Assuming the test is as follows:

$\mathrm{H}_{0}$ : Distribution is Normal (Sig $\left.\geq 0.05\right)$.

$\mathrm{H}_{1}$ : Distribution isn't Normal (Sig < 0.05).

Table3. Table Kolmogorov - Smirnov test

\begin{tabular}{|l|c|c|c|c|c|c|c|c|}
\hline & $\mathrm{R}$ & $\mathrm{E}$ & $\mathrm{RE}$ & $\mathrm{F}$ & $\mathrm{P}$ & $\mathrm{WD}$ & $\mathrm{SQ}$ & SAT \\
\hline Number & 384 & 384 & 384 & 384 & 384 & 384 & 384 & 384 \\
\hline
\end{tabular}




\begin{tabular}{|l|c|c|c|c|c|c|c|c|}
\hline Average & 21.2734 & 20.7214 & 19.6120 & 10.4219 & 13.7526 & 13.2214 & 99.0026 & 41.0703 \\
\hline Standard deviation & 2.51382 & 2.68891 & 3.59401 & 1.68673 & 2.43640 & 2.21565 & 9.59942 & 5.21774 \\
\hline Test & 2.124 & 2.112 & 2.401 & 2.505 & 2.367 & 2.570 & 1.230 & 1,470 \\
\hline Significant & .000 & .000 & .000 & .000 & .000 & .000 & 0.097 & 0.027 \\
\hline
\end{tabular}

Due to Table 3 and the value obtained for the $p$-value $95 \%$ confidence level, the significant level $\alpha=0.05$ Observations strongly suggest he is more research hypothesis $\left(H_{0}\right)$ Are rejected, with $95 \%$ so it could be claimed that any of the independent variables and the dependent variable follows a normal distribution. Therefore, it is necessary to analyze data by using non-parametric tests.

To investigate the correlation between variables, Spearman correlation coefficient (non-parametric) was used. Table 4 shows the correlation of the variables.

Table4.The coefficient correlation between original research variables and customer satisfaction

\begin{tabular}{|l|c|c|c|c|c|c|}
\hline Dependent variable & Reliability & Efficiency & Responsiveness & fulfillment & Privacy / Security & Web design \\
\hline Quality of Service & 0.534 & 0.524 & 0.725 & 0.507 & 0.582 & 0.737 \\
\hline Sig. & 0.000 & 0.000 & 0.000 & 0.000 & 0.000 & 0.000 \\
\hline
\end{tabular}

According to Table 4 at a confidence level of $99 \%$ of $p$-value Relationship between the dependent variable is equal to 0.000 for service quality in internet banking and independent variables, reliability, efficiency, Responsiveness, fulfillment, privacy / security and website design is approved. Therefore, hypothesizes 1 to 6 is confirmed.

For test of hypothesis 7, Spearman coefficient correlation was used, too. Coefficient correlation was equivalent to 0.754 in the significant level $\alpha=0.01$. Therefore, hypothesis 7 is confirmed

To test the hypothesis8 Kruskal-Wallis test that a test for non-parametric for comparison of three or more independent groups, are used. Table 5 Average ratings for each group, and Table 6 shows the test output.

Table5. Average rating banks with Kruskal-Wallis test

\begin{tabular}{|c|c|c|}
\hline Bank & Number & Average rating \\
\hline Customer satisfaction Mellat & 70 & 180.99 \\
Tejarat & 99 & 165.07 \\
Parsian & 70 & 199.81 \\
Pasargad & 63 & 193.78 \\
Melli & 61 & 178.02 \\
& & \\
\hline
\end{tabular}

Table6. The Kruskal-Wallis test

\begin{tabular}{|l|c|}
\hline & Customer satisfaction \\
\hline Chi-square & 5.508 \\
Degrees of freedom & 4 \\
Sig. & 0.239 \\
\hline
\end{tabular}


With respect to the table 5, the mean rank difference is not confirmed. Table 5 and Table 6 is shown sig $\geq 0.05$ then the hypothesis 8 is rejected.

At the end of the study, six dimensions- reliability, efficiency, responsiveness, fulfillment, security/ privacy and website design examined to determine the ranking, the importance of each of these factors in increased satisfaction in Internet banking. The Freedman test was used. Table 7 is shown sig. $=0.00$, it means average of variables are significantly different from each of the five variables of satisfaction will increase. Reliability has most influence on customer satisfaction and Website design has less influence on customer satisfaction in Internet Banking.

Table7. Freedman Test (output of software)

\begin{tabular}{|l|c|}
\hline Variables & Average ratings \\
\hline Reliability & 4.05 \\
\hline fulfillment & 3.75 \\
\hline Efficiency & 3.68 \\
\hline Privacy / Security & 3.48 \\
\hline Responsibility & 3.11 \\
\hline Website Design & 2.94 \\
\hline The numbers of the test oven to Enter \\
\hline Number & 384 \\
Chi & 100.861 \\
Degrees of freedom & 5 \\
Significance level estimated & 0.000 \\
\hline
\end{tabular}

\section{Conclusions}

In present research based on the previous literature, reliability, efficiency, responsiveness, fulfillment, security/privacy and website design as internet banking service quality dimensions were identified and proposed indicators to measure customer satisfaction with service quality customer Surveys confirmed. Therefore be acknowledged that these indicators are presented to evaluate the service quality and customer satisfaction as a result of Internet banking works in Iran. The results indicate that the reliability index has the most effective and website design has the least effective on customer satisfaction than other indicators. Since the average customer satisfaction does not differ between the websites of different banks can be the result of different banks in our country in terms of quality of Web services is not statistically significant. As a proposal for a study of the future, implementation of this model in banks and recognized the results was the investigation system has been designed in this research recommended in other electronic organizations.

\section{References}

[1] E.M. Awad, The Structure of E-commerce in the Banking industry: An Empirical Investigation, SIGCPR2000 Evanston Illinois USA.

[2] M.M Anuar, F. Adam, and Z. Mohammad, Muslim consumers' perception on Internet Banking services, International Journal of Business and social Science, Vol. 3, No. 5, (2012) 63-71. 
[3] M. Fasanghari, and F. Roudsari H., the Fuzzy Evaluation of E-Commerce Customer Satisfaction, World Applied Science Journal, Vol. 4, No.2, (2008) 164-168.

[4] R.A. Gbadeyan and O.O. Akinyosoye-Gbonda, Customers' Preference For E-Banking Services: A Case study of Selected Banks in Sierra Leone, Australian Journal of Business and Management Research, Vol.1, No.4, (2011) 108-116.

[5] M. Jayanthy, and R. Umarani ,Customers' perception and satisfaction towards internet banking services, International Journal of Multidisciplinary Research ,Vol. 2,No. 8, August ,(2012),ISSN 22315780.

[6] V.M. Kumbhar, Factors affecting the customer satisfaction in e-banking: some evidences from Indian banks, Management research and practice, Vol. 3, No.4, (2011) 1-14.

[7] C.C. Lin, A critical appraisal of customer satisfaction and e-Commerce, Managerial Auditing Journal, Vol.18, No. 3, (2003).

[8] C. Liu and K. P. Arnett, Exploring in the Factors Associated with Web Site Success in the Context of Electronic Commerce , Information and Management, No 38(1),(2000) 23-34.

[9] E. Lociacono, R.T. Watson and D. Goodhue, WebQual тм: A web site Quality Instrument, Working Paper. Worcester Polytechnic Institute (2000).

[10] R. Mekovec, K. Kero, E-Service quality: a case study of Varazdin County, $26^{\text {th }}$ International Conference on Organizational Science Development CREATIVE ORGANIZATION, March 28-30, (2007), Protozoa, Slovenia.

[11] A. Musiime, R. Malinga, Internet banking, Consumer adoption and Customer satisfaction, African Journal of Marketing Management, Vol.3, No.10, (2011) 261-269.

[12] M. P. Neghab S. M. Heravi and M. Kahani, Simulation and Optimization of Affective Causes on Quality of Electronic Services, Journal of Mathematics and Computer Science, Vol. 7, (2013), 23-32.

[13] J. M. Nupur, E-Banking and Customer Satisfaction in Bangladesh: An Analysis, International Review of Business Research Papers, Vol. 6, No 4, (2010) 145-156.

[14] B. Saeidipour, T. Vatandost and P. Akbari , Study the Effect of Development of Electronic Banking on Customer Satisfaction Levels by Using Kano Model (Case study : Refah Bank of Kermanshah, Iran),International Research Journal of Applied and Basic Sciences, Vol.3, No5, (2012) 950-960.

[15] P. Saha and Y. Zhao, Relationship between online Service Quality and Customer Satisfaction, Lule University of Technology MSc Program me in Electronic Commerce (2005).

[16] A. Timothy, Electronic Banking Services and Customer Satisfaction in the Nigerian Banking Industry, International Journal of Business and Management Tomorrow, Vol.2, No. 3, (2012) 1-8.

[17] N. M. Toosi, R. A. Kohanali, The study of airline service quality in the Qeshm free Zone by fuzzy logic, Journal of Mathematics and Computer Science, Vol. 2, No. 1, (2011), 171-183.

[18] H.W. Webb and L. Webb, Site Qual: An Integrated Measure of Website Quality, the Journal of Enterprise Information Management, Vol.17, No.6, (2004)430-440.

[19] M. F. Wolfinberger and M. C. Gilly,.com Q :Dimensional zing ,measuring and Predicting Quality of the E-tail Experience, Working Paper No.02-100.Marketing Science Institute, Cambridge, MA, (2002).

[20] M. F. Wolfinberger and M. C. Gilly, e Tail Q: Dimensional zing, measuring and predicting e Tail Quality, Journal of retailing, Vol.79, (2003)183-198.

[21] A. Zeithaml Valarie, A. Parasuraman and A. Malhotra, A Conceptual Framework for Understanding e-Service Quality: Implications for Future Research and Managerial practice: Working Paper, Cambridge M.A, Marketing Science Institute, Report Number 00-115, (2000).

[22] A. Zeithaml Valarie, A. Parasuraman and A. Malhotra, Service Quality Delivery Through Web Sites :A Critical Review of Extant Knowledge, Journal of the Academy of Marketing Science, Vol. 30, No4, (2002) 358-371. 